\title{
A simple two-step synthesis of 2-(alkylamino)-1-arylethanols, including racemic adrenaline, from aromatic aldehydes via 5-aryloxazolidines
}

\author{
Vladimir S. Moshkin*, Vyacheslav Ya. Sosnovskikh \\ Department of Chemistry, Ural Federal University, prosp. Lenina 51, 620000 Ekaterinburg, Russia
}

\section{A R T I C L E I N F O}

\section{Article history:}

Received 18 June 2013

Revised 1 August 2013

Accepted 21 August 2013

Available online 30 August 2013

\section{Keywords:}

Benzaldehydes

Nonstabilized azomethine ylides

[3+2] Cycloaddition

5-Aryloxazolidines

Phenethylamines

Epinephrine (adrenaline)

\begin{abstract}
A B S T R A C T
Benzaldehydes react smoothly with nonstabilized azomethine ylides, generated in situ from sarcosine/ formaldehyde or $\mathrm{N}$-(methoxymethyl)- $\mathrm{N}$-(trimethylsilylmethyl)benzylamine, to give 5-aryloxazolidines as intermediates. These were converted into 2-(alkylamino)-1-arylethanols in good yields by simple heating in methanol with hydrochloric acid, or by treatment with hydrazine hydrate in ethanol.
\end{abstract}

(c) 2013 Elsevier Ltd. All rights reserved.
The chemistry of $\beta$-hydroxy- $\beta$-phenethylamines has attracted considerable attention from the synthetic community due to their wide distribution in Nature and various biological activities. ${ }^{1}$ Examples of such compounds include the alkaloids halostochine (1a), longimammine (1b), and normacromerine (1c), as well as the drugs phenylephrine (1d) and epinephrine (1e) (Fig. 1). ${ }^{2}$ The latter, also known as adrenaline, 1-(3,4-dihydroxyphenyl)-2(methylamino)ethanol, is a naturally occurring hormone and a neurotransmitter, which has many functions in the body, regulating heart rate, blood vessel and air passage diameters. It has many clinical uses due to its potent actions on the heart, and on vascular and other smooth muscles; it also acts as a cardiac stimulant and has effects on gastrointestinal, uterine, and bronchial muscles. ${ }^{3}$

Due to the important applications of this class of compounds, their synthesis has been studied extensively. ${ }^{4}$ Most pertinent to the present research are the reactions involving the oxazolidine system as a starting material. To the best of our knowledge, there are only two related examples reported in the literature. In 1970, Rizzi investigated the reaction of benzaldehyde and $m$-benzyloxybenzaldehyde with sarcosine and obtained diaryloxazolidines, which were subsequently hydrolyzed with hydrochloric acid to form halostochine (1a) and debenzylated into phenylephrine (1d) in low yields. ${ }^{5}$ Later, Orsini found that the intermediate unsym-

\footnotetext{
* Corresponding author. Fax: +7 3432615978.

E-mail address: mvslc@mail.ru (V.S. Moshkin).
}

metrical nonstabilized azomethine ylides generated from sarcosine and aromatic aldehydes reacted with a second molecule of aldehyde to produce a mixture of regioisomeric diaryloxazolidines, which resulted in low yields during the Rizzi synthesis. ${ }^{6}$

In connection with our interest in azomethine ylide chemistry, ${ }^{7}$ we have developed convenient methods for the preparation of 1,2,3,4-tetrahydroisoquinolin-4-ols $\quad 3, \quad N$-benzyl- $\beta$-hydroxy- $\beta$ phenethylamines $\mathbf{4}$, and 4-aryl-1,2,3,4-tetrahydroisoquinolines $\mathbf{5}$<smiles>CNCC(O)c1ccccc1</smiles><smiles>CNCC(O)c1ccc(OC)cc1</smiles><smiles>CNCC(O)c1ccc(OC)c(OC)c1</smiles><smiles>CNCC(O)c1cccc(O)c1</smiles><smiles>CNC[C@H](O)c1ccc(O)c(O)c1</smiles>

Figure 1. Examples of valuable 1-aryl-2-(methylamino)ethanols. 
from aromatic aldehydes and an azomethine ylide derived from sarcosine and formaldehyde, via intermediate 5-aryloxazolidines 2. ${ }^{8}$ Taking into account these results, we envisaged that the ringopening of oxazolidines $\mathbf{2}$ by removing the semi-aminal methylene group would produce the corresponding 1-aryl-2-(methylamino)ethanols $\mathbf{1}$, and may provide a general and simple route for the synthesis of these important amino alcohols. To the best of our knowledge, no such approach has been reported previously (Scheme 1).

To test the feasibility of this idea, the reaction of 3-methyl-5phenyloxazolidine ( $\mathbf{2 a}, \mathrm{R}=\mathrm{H}$ ), obtained from benzaldehyde, sarcosine, and paraformaldehyde, with methanol was first investigated. We found that refluxing 2a, methanol, and concentrated $\mathrm{HCl}$ ( 1.2 equiv) for $1.5 \mathrm{~h}$ resulted in the formation of desired halostochine (1a) in $61 \%$ overall yield, based on the starting aromatic aldehyde. ${ }^{9}$ Using this approach, we were also able to obtain 1-(4bromophenyl)-2-(methylamino)ethanol (1f) and 2-(methylamino)-1-(4-nitrophenyl)ethanol (19) from the corresponding benzaldehydes in $59 \%$ and $63 \%$ yields, respectively (Scheme 2, Table 1). It should be noted that this reaction does not require any chromatographic purification of the intermediate liquid oxazolidines $\mathbf{2}$ or the products $\mathbf{1}$, and thereby greatly facilitates the preparation of the target arylethanolamines. However, anisaldehyde, under the same conditions, gave a mixture of products, presumably due to the high nucleophilicity of the benzene ring and the stabilizing effect of the $p$-methoxy group on the benzylic<smiles>[R]c1ccc(C(O)C[N+](=C)C)cc1</smiles><smiles>[R]c1ccc(C(O)CNNC)cc1</smiles>

Scheme 1. One-pot syntheses of phenethylamine derivatives.<smiles>[R]c1ccc(C2CN(C)CO2)cc1</smiles><smiles>CC(C)(C)CNC(O)c1ccc(O)c(O)c1</smiles>

carbocation intermediate, which facilitate intermolecular side reactions.

This problem can be overcome by using a previously reported demethylenation protocol on the oxazolidine ring with hydrazine hydrate in ethanol. ${ }^{10}$ To our delight, this procedure gave longimammine (1b) in 70\% yield from the starting anisaldehyde; normacromerine (1c) was obtained from veratraldehyde in a similar way in 59\% yield. Analogous reactions with 2,4-dimethoxybenzal-

Table 1

Yields and melting points of $\beta$-hydroxy- $\beta$-phenethylamines $\mathbf{1}$

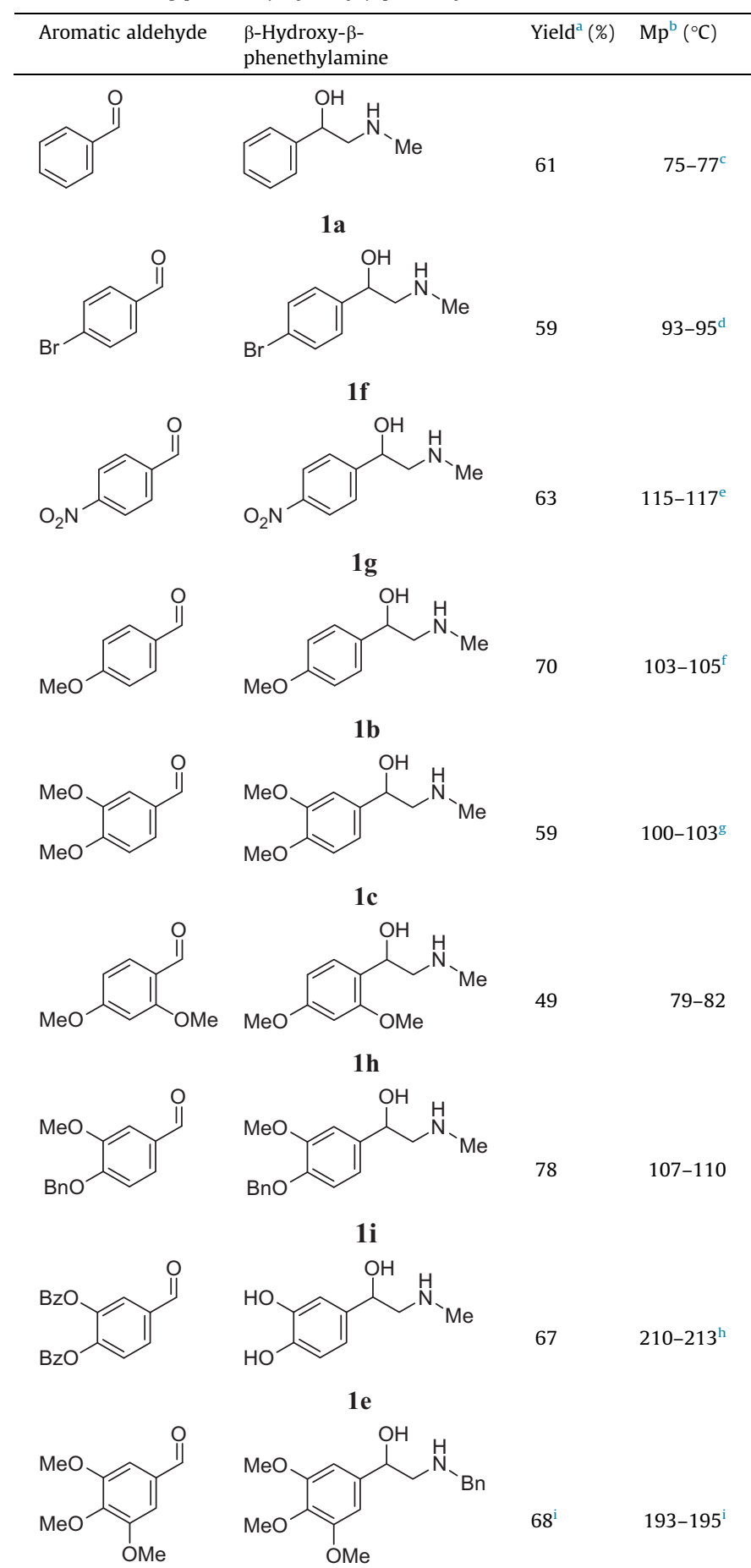

Scheme 2. Synthesis of $\beta$-hydroxy- $\beta$-phenethylamines 1. Reaction conditions: (i) $\mathrm{MeOH}, \mathrm{HCl}$, reflux, $1.5 \mathrm{~h}$; (ii) EtOH, $\mathrm{N}_{2} \mathrm{H}_{4} \cdot \mathrm{H}_{2} \mathrm{O}$, rt (2 d), reflux (3 h). 
Table 1 (continued)

\begin{tabular}{llll}
\hline Aromatic aldehyde & $\begin{array}{l}\beta \text {-Hydroxy- } \beta- \\
\text { phenethylamine }\end{array}$ & Yield $^{\mathrm{a}}(\%)$ & $\mathrm{Mp}^{\mathrm{b}}\left({ }^{\circ} \mathrm{C}\right)$ \\
\hline $\mathbf{1 k}$ & & & \\
& &
\end{tabular}

a Overall yield of phenylethylamine based on the starting aromatic aldehyde.

b Melting points are uncorrected.

c $\mathrm{Mp} 75.5-76.5^{\circ} \mathrm{C},{ }^{5} \mathrm{mp} 71-74^{\circ} \mathrm{C}^{13}$

d $\mathrm{Mp} 91.5-93.7^{\circ} \mathrm{C} . .^{14}$

e $\mathrm{Mp} 117^{\circ} \mathrm{C},{ }^{15} \mathrm{mp} 95-98^{\circ} \mathrm{C} .^{16}$

f $\mathrm{Mp} 106-107^{\circ} \mathrm{C} .{ }^{17}$

g $\mathrm{Mp} 105-106^{\circ} \mathrm{C},{ }^{19} \mathrm{mp} 107-108.5^{\circ} \mathrm{C} .^{2 \mathrm{c}}$

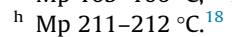

i Yield and $\mathrm{mp}$ of the hydrochloride.

${ }^{j} \mathrm{Mp} 84-85^{\circ} \mathrm{C} .{ }^{20}$

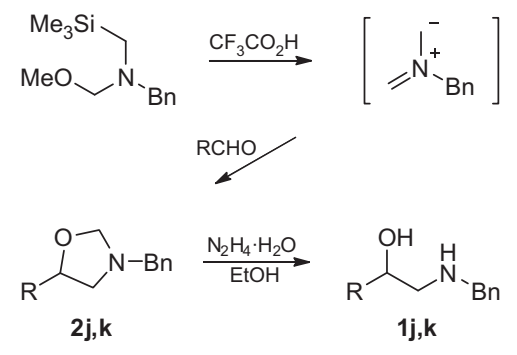

Scheme 3. Synthesis of compounds $\mathbf{1 j}, \mathbf{k}$.

dehyde and 4-benzyloxy-3-methoxybenzaldehyde resulted in the formation of previously unknown $\beta$-hydroxy- $\beta$-phenethylamines 1h and 1i. ${ }^{11}$ Finally, epinephrine (1e) was synthesized from 3,4dibenzoyloxybenzaldehyde in $67 \%$ yield. In this case, the benzoyl protection was removed simultaneously by demethylenation of oxazolidine $\mathbf{2 e}$ under the action of hydrazine hydrate (Scheme 2, Table 1).

An alternative method for the generation of a nonstabilized azomethine ylide from $N$-(methoxymethyl)- $N$-(trimethylsilylmethyl)benzylamine in the presence of trifluoroacetic acid, ${ }^{12}$ followed by hydrazinolysis of oxazolidine $\mathbf{2} \mathbf{j}$ allowed us to obtain $\mathrm{N}$-benzyl derivative $\mathbf{1 j}$ isolated as the hydrochloride. Application of this reaction to thiophene-2-carbaldehyde led to a two-step synthesis of 2-(benzylamino)-1-(thien-2-yl)ethanol (1k) in 71\% yield (Scheme 3).

In conclusion, we have developed a practical, two-step route to $N$-alkyl- $\beta$-hydroxy- $\beta$-phenethylamines from aromatic aldehydes via a 5-aryloxazolidine intermediate, followed by its demethylenation. This one-pot synthesis can be considered as a formal $C$-nucleophilic addition of the methyl(benzyl)aminomethyl anion ${ }^{21}$ from sarcosine/formaldehyde or $N$-(methoxymethyl)- $N$-(trimethylsilylmethyl)benzylamine to the aldehyde carbonyl group. The proposed method allows easy access to biologically important phenethylamine derivatives. Further studies on this reaction are underway in our laboratory and the results will be reported in due course.

\section{Acknowledgments}

The research was carried out under the terms of the Ural Federal University development program with the financial support of young scientists, and was supported financially by RFBR (Grant 12-03-31036).

\section{Supplementary data}

Supplementary data associated with this article can be found, in the online version, at http://dx.doi.org/10.1016/ j.tetlet.2013.08.083.

\section{References and notes}

1. (a) Griffith, R. K. Adrenergics and Adrenergic-Blocking Agents. In Burger's Medicinal Chemistry and Drug Discovery; Abraham, D. J., Ed., 6th ed.; John Wiley \& Sons: New York, 2003; Vol. 6, pp 1-37; (b) Westfall, T. C.; Westfall, D. P. Adrenergic Agonists and Antagonists. In Goodman \& Gilman's the Pharmacological Basis of Therapeutics; Brunton, L. L., Chabner, B. A., Knollmann, B. C., Eds., 12th ed.; McGraw-Hill: New York, 2011; pp 277-334; (c) Avakyan, O. M. Pharmacological Regulation of Adrenoceptor Function; Meditsina: Moscow, Russia, 1988.

2. (a) Keller, W. J.; McLaughlin, J. L. J. Pharm. Sci. 1972, 61, 147-148; (b) Ranieri, R. L.; McLaughlin, J. L. J. Org. Chem. 1976, 41, 319-323; (c) Brown, S. D.; Hodgkins, J. E.; Reinecke, M. G. J. Org. Chem. 1972, 37, 773-775.

3. (a) Guimarães, S.; Moura, D. Pharmacol. Rev. 2001, 53, 319-356; (b) Bernini, R.; Crisante, F.; Barontini, M.; Fabrizi, G. Synthesis 2009, 3838-3842.

4. (a) Kolshorn, E. Chem. Ber. 1904, 37, 2474-2486; (b) Rosenmund, K. W. Chem. Ber. 1913, 46, 1034-1050; (c) Mannich, C.; Thiele, E. Arch. Pharm. 1915, 253. 181-195; (d) Boyer, J. H. J. Am. Chem. Soc. 1951, 73, 5865-5866; (e) Burger, A.; Hornbaker, E. D. J. Am. Chem. Soc. 1952, 74, 5514; (f) Castro, A. J.; Brain, D. K.; Fisher, H. D.; Fuller, R. K. J. Org. Chem. 1954, 19, 1444-1448; (g) Tanaka, K.; Mori, A.; Inoue, S. J. Org. Chem. 1990, 55, 181-185; (h) Nyerges, M.; Fejes, I.; Virányi, A.; Groundwater, P. W.; Töke, L. Synthesis 2001, 1479-1482; (i) Tanaka, I. Iwase, U. JP Patent 37015619, 1962; Chem. Abstr. 1963, 59, 62340.

5. Rizzi, G. P. J. Org. Chem. 1970, 35, 2069-2072.

6. Orsini, F.; Pelizzoni, F.; Forte, M.; Destro, R.; Gariboldi, P. Tetrahedron 1988, 44, 519-541.

7. (a) Moshkin, V. S. Sosnovskikh, V. Y: Slepukhin, P. A. Röschenthaler, G.-V. Mendeleev Commun. 2012, 22, 29-31; (b) Moshkin, V. S.; Sosnovskikh, V. Y.; Röschenthaler, G.-V. Tetrahedron Lett. 2012, 53, 3568-3572; (c) Moshkin, V. S.; Sosnovskikh, V. Y.; Röschenthaler, G.-V. Tetrahedron 2013, 69, 5884-5892.

8. (a) Moshkin, V. S.; Sosnovskikh, V. Y. Tetrahedron Lett. 2013, 54, 2455-2457; (b) Moshkin, V. S.; Sosnovskikh, V. Y. Tetrahedron Lett. 2013, 54, 2699-2702.

9. General procedures for the preparation of 2-(alkylamino)-1-arylethanols 1 a-c $\boldsymbol{f}-\boldsymbol{i}$. A mixture of the corresponding aromatic aldehyde $(1.0 \mathrm{mmol})$, finely ground sarcosine $(0.13 \mathrm{~g}, 1.5 \mathrm{mmol})$, and paraformaldehyde $(0.09 \mathrm{~g}, 3.0 \mathrm{mmol})$ was refluxed in dry benzene $(3.3 \mathrm{~mL})$, with magnetic stirring and removal of formed water by means of a Dean-Stark trap, for $6-8 \mathrm{~h}$. The resulting solution was evaporated in vacuo to give the oily 5-aryl-3-methyloxazolidines $2 \boldsymbol{a}$-c $\boldsymbol{f}$ - $\boldsymbol{i}$, which were used without additional purification.

For the preparation of amino alcohols $\mathbf{1 a}, \boldsymbol{f}$,g: the corresponding oily oxazolidine $\mathbf{2}$ was dissolved in $\mathrm{MeOH}(1 \mathrm{~mL})$ and treated with concentrated $\mathrm{HCl}(0.10 \mathrm{~mL}$, $1.2 \mathrm{mmol}$ ). The resulting mixture was refluxed in a fume hood with partial evaporation of the solvent for $1.5 \mathrm{~h}$ (for the removing of dimethoxymethane). The $\mathrm{MeOH}$ was evaporated in vacuo and $\mathrm{H}_{2} \mathrm{O}(0.5 \mathrm{~mL})$ was added. The mixture was extracted with $\mathrm{Et}_{2} \mathrm{O}(2 \times 1 \mathrm{~mL})$ followed by basification with an excess of a cold concentrated solution of $\mathrm{NaOH}$. Extraction with $\mathrm{CH}_{2} \mathrm{Cl}_{2}(2 \times 2 \mathrm{~mL})$, drying over $\mathrm{Na}_{2} \mathrm{SO}_{4}$, and evaporation gave the crude 1-aryl-2-(methylamino)ethanol, which was recrystallized from $\mathrm{CH}_{2} \mathrm{Cl}_{2}$-heptane mixture.

For the preparation of amino alcohols $\mathbf{1 b}, \boldsymbol{c}, \boldsymbol{h}, \boldsymbol{i}$ : the corresponding oily oxazolidine 2 was dissolved in EtOH $(1 \mathrm{~mL})$ and treated with hydrazine hydrate $(0.4 \mathrm{~mL})$. The resulting mixture was left at room temperature for $2 \mathrm{~d}$ and then refluxed for $3 \mathrm{~h}$. The solvents were evaporated in vacuo and a concentrated aqueous solution of $\mathrm{NaOH}$ was added to the residue. Extraction with $\mathrm{CH}_{2} \mathrm{Cl}_{2}(2 \times 2 \mathrm{~mL})$, drying over $\mathrm{Na}_{2} \mathrm{SO}_{4}$, and evaporation gave the crude 1-aryl-2(methylamino)ethanol, which was recrystallized from $\mathrm{CH}_{2} \mathrm{Cl}_{2}$-heptane mixture.

10. Madesclaire, M.; Couquelet, J.; Leal, F.; Zaitsev, V. P.; Sharipova, S. K. Chem. Heterocycl. Compd. 2002, 38, 71-73.

11. 1-(2,4-Dimethoxyphenyl)-2-(methylamino)ethanol (1h). Colorless crystals, yield $49 \%, \mathrm{mp} 79-82{ }^{\circ} \mathrm{C}$ (heptane- $\mathrm{CH}_{2} \mathrm{Cl}_{2}$ ). ${ }^{1} \mathrm{H}$ NMR (400 MHz, DMSO- $\left.d_{6}\right) \delta 2.29$ (s, $3 \mathrm{H}, \mathrm{MeN}), 2.42(\mathrm{dd}, J=11.9,8.5 \mathrm{~Hz}, 1 \mathrm{H}, \mathrm{CHH}), 2.54(\mathrm{dd}, J=11.9,3.1 \mathrm{~Hz}, 1 \mathrm{H}$, $\mathrm{CHH}), 3.74(\mathrm{~s}, 3 \mathrm{H}, \mathrm{MeO}), 3.75(\mathrm{~s}, 3 \mathrm{H}, \mathrm{MeO}), 4.88(\mathrm{dd}, J=8.5,3.1 \mathrm{~Hz}, 1 \mathrm{H}, \mathrm{CH})$, 6.47-6.52 (m, 2H, ArH), 7.26-7.30 (m, 1H, ArH); ${ }^{13} \mathrm{C}$ NMR (101 MHz, DMSO-d $\left.d_{6}\right)$ $\delta$ 35.9, 55.1, 55.3, 58.6, 65.1, 97.9, 104.5, 124.7, 127.0, 156.6, 159.3. Anal. Calcd for $\mathrm{C}_{11} \mathrm{H}_{17} \mathrm{NO}_{3}$ : C, 62.54; H, 8.11; N, 6.63. Found: C, 62.76; H, 7.88; N, 6.67.

1-[4-(Benzyloxy)-3-methoxyphenyl]-2-(methylamino)ethanol (1i). Colorless crystals, yield $78 \%, \mathrm{mp} 107-110{ }^{\circ} \mathrm{C}$ (heptane- $\left.\mathrm{CH}_{2} \mathrm{Cl}_{2}\right) .{ }^{1} \mathrm{H}$ NMR $(400 \mathrm{MHz}$, DMSO $_{6}$ ) $\delta 2.31(\mathrm{~s}, 3 \mathrm{H}, \mathrm{MeN}), 2.56(\mathrm{dd}, J=12.0,4.8 \mathrm{~Hz}, 1 \mathrm{H}, \mathrm{CHH}), 2.61(\mathrm{dd}$, $J=12.0,7.6 \mathrm{~Hz}, 1 \mathrm{H}, \mathrm{CHH}), 3.77(\mathrm{~s}, 3 \mathrm{H}, \mathrm{MeO}), 4.59(\mathrm{dd}, J=7.6,4.8 \mathrm{~Hz}, 1 \mathrm{H}, \mathrm{CH})$, $5.05\left(\mathrm{~s}, 2 \mathrm{H}, \mathrm{CH}_{2} \mathrm{O}\right.$ ), 6.83 (dd, $\left.J=8.2,1.5 \mathrm{~Hz}, 1 \mathrm{H}, \mathrm{H}-6\right), 6.96$ (d, $J=8.2 \mathrm{~Hz}, 1 \mathrm{H}, \mathrm{H}-$ 5), $6.98(\mathrm{~d}, J=1.5 \mathrm{~Hz}, 1 \mathrm{H}, \mathrm{H}-2), 7.32(\mathrm{t}, J=7.1 \mathrm{~Hz}, 1 \mathrm{H}, \mathrm{Ph}), 7.39(\mathrm{t}, J=7.1 \mathrm{~Hz}, 2 \mathrm{H}$, $\mathrm{Ph}), 7.44(\mathrm{~d}, J=7.1 \mathrm{~Hz}, 2 \mathrm{H}, \mathrm{Ph}) ;{ }^{13} \mathrm{C}$ NMR $\left(101 \mathrm{MHz}, \mathrm{DMSO}-d_{6}\right) \delta 35.8,55.5,59.7$, 70.0, 70.8, 110.1, 113.4, 117.9, 127.68, 127.74, 128.4, 137.4, 137.7, 146.7, 148.9. Anal. Calcd for $\mathrm{C}_{17} \mathrm{H}_{21} \mathrm{NO}_{3}$ : C, 71.06; H, 7.37; N, 4.87. Found: C, 70.67; H, 7.43; N, 4.99 .

2-Benzylamino-1-(3,4,5-trimethoxyphenyl)ethanol hydrochloride (1j). Colorless crystals, yield $68 \%, \mathrm{mp} 193-195{ }^{\circ} \mathrm{C}(\mathrm{i}-\mathrm{PrOH}) .{ }^{1} \mathrm{H}$ NMR $\left(400 \mathrm{MHz}, \mathrm{D}_{2} \mathrm{O}\right) \delta 3.30$ (dd, $J=13.0,8.8 \mathrm{~Hz}, 1 \mathrm{H}, \mathrm{CHH}$ ), 3.36 (dd, $J=13.0,3.7 \mathrm{~Hz}, 1 \mathrm{H}, \mathrm{CHH}), 3.81$ (s, 3H, 
$\mathrm{MeO}), 3.89(\mathrm{~s}, 6 \mathrm{H}, 2 \mathrm{MeO}), 4.35\left(\mathrm{~s}, 2 \mathrm{H}, \mathrm{CH}_{2} \mathrm{~N}\right), 5.06(\mathrm{dd}, J=8.8,3.7 \mathrm{~Hz}, 1 \mathrm{H}, \mathrm{CH})$ $6.78(\mathrm{~s}, 2 \mathrm{H}, \mathrm{H}-2, \mathrm{H}-6), 7.49-7.55(\mathrm{~m}, 5 \mathrm{H}, \mathrm{Ph}) ;{ }^{13} \mathrm{C} \mathrm{NMR}\left(101 \mathrm{MHz}, \mathrm{D}_{2} \mathrm{O}\right) \delta 53.5$, 54.7, 58.6, 63.4, 71.3, 105.7, 131.8, 132.3, 132.4, 132.8, 138.9, 139.0, 155.2. Anal. Calcd for $\mathrm{C}_{18} \mathrm{H}_{24} \mathrm{ClNO}_{4}$ : C, 61.10; H, 6.84; N, 3.96. Found: C, 61.18; H, 7.09; N, 3.99 .

12. Ryan, J. H.; Spiccia, N.; Wong, L. S.-M.; Holmes, A. B. Aust. J. Chem. 2007, 60, 898-904.

13. Peterson, D. J.; Ward, J. F. J. Organomet. Chem. 1974, 66, 209-217.

14. Guo, Z. Cheng, G. Chu, F. U.S. Patent 20040029951, 2004; Chem. Abstr. 2004 140,181319

15. Teotino, U. M.; Friz, P. L.; Steis, G.; Bella, D. D. Farmaco, Ed. Sci. 1962, 17, $252-$
16. Crist, D. R.; Jordan, G. J.; Moore, D. W.; Hashmall, J. A.; Borsetti, A. P.; Turujman, S. A. J. Am. Chem. Soc. 1983, 105, 4136-4142.

17. Bergmann, E. D.; Sulzbacher, M. J. Org. Chem. 1951, 16, 84-89.

18. (a) Sinsheimer, J. E.; Smith, E. J. Pharm. Sci. 1963, 52, 1080-1085; (b) Jameson, R. E. Neillie, W. F. S. J. Chem. Soc. 1965, 2391-2395.

19. Mannich, C. Arch. Pharm. 1910, 248, 127-171.

20. Carissimi, M.; Picciola, G.; Ravenna, F.; Carenini, G.; Gentili, P. Farmaco, Ed. Sci. $1980,35,812-825$

21. (a) Guijarro, A.; Ortiz, J.; Yus, M. Tetrahedron Lett. 1996, 37, 5597-5600; (b) Ortiz, J.; Guijarro, A.; Yus, M. Tetrahedron 1999, 55, 4831-4842. 